\title{
A shotgun marriage - employment equity and human resource planning
}

\author{
Michèle Boonzaier \& Billy Boonzaier \\ Management School, Cape Technikon, P.O. Box 652, Cape Town, 8000 South Africa
}

Received January 1999

\begin{abstract}
The current state of human resource planning in South Africa is that many companies conduct virtually no such planning or provide it only for senior managerial positions. Employment equity legislation will, however, force the hand of managers and human resource practitioners in the public and private sectors alike to engage in regular human resource planning. The Employment Equity Act (1998) seeks to address the existing discrepancies in the distribution of jobs, occupations and income amongst South Africans by not only eliminating unfair discrimination in employment, but also making provision for affirmative action measures to promote a diverse and representative workforce. The employment equity audit requires the preparation of a workforce profile and consequent employment equity plan to address discrepancies. The main purpose of human resource planning is to identify future human resource requirements (in terms of numbers, skills, and particular characteristics, inter alia gender, race and disability) and to develop action plans to eliminate any discrepancies between the demand and supply of labour that are forecast. The article presents a comprehensive model of human resource planning, incorporating the practical implications of the Employment Equity Act, as a workable guideline to assist managers in compiling thorough forecasts and action plans in fulfilment of organizational and employment equity requirements.
\end{abstract}

\section{Introduction}

The Employment Equity Act of 1998 (the Act), apart from prohibiting any form of unfair discrimination in employment, will directly affect many employers by requiring them to prepare and implement employment equity plans to rectify imbalances between their current workforce profile and the demographic profile of the national and regional economically active population. Employment equity and concomitant affirmative action (Government Gazette, 19 October 1998) are thus placed squarely and unavoidably on management's strategic planning agenda.

However, if management were to plan and execute employment equity within the broader context of a more extensive planning process, namely human resource planning, the impact and effectiveness of the outcome would be magnified, and coincide not only with the legislative requirements thrust upon them, but with the business requirements of their organization as well.

Presented now is a juxtaposition of certain aspects of both concepts, namely the nature, purpose and responsibility for human resource planning and employment equity. This is followed by an exposition of the human resource planning process, specifying in addition such actions and considerations as are necessary to satisfy employment equity requirements.

\footnotetext{
Nature of human resource planning and employment equity

Nature of human resource planning

Human resource planning can be viewed as the process of developing and implementing plans and programmes to ensure that the right numbers and types of individuals are available at the right time and place to perform the work necessary to achieve the organization's objectives (Dolan \& Schuler, 1987: 41). Human resource planning addresses the major objectives of the organization in that it spells out what types of people will in future be needed to execute the work required to accomplish the business goals of the organization, and must as such be directly linked to strategic business
}

planning (Swanepoel, Erasmus, Van Wyk \& Schenk, 1998: 273). Strategic planning includes the formulation of strategies, goals and objectives for the organization, and is of necessity the foundation of human resource planning. French (1994: 131) emphasizes the continuous nature of human resource planning within the context of strategic planning and the changing conditions both within and outside the organization. This implies that the structure of the organization, the specific jobs to be performed, the financial and technological resources allocated, and the types and numbers of people employed, must always reflect the general strategies and goals of the organization (Swanepoel et al., 1998: 273).

Hercus (1993: 405) summarizes human resource planning by stating that it is a management process involving the following elements:

- forecasting human resource requirements for an organization to execute its business plan;

- forecasting human resources available for meeting these needs and doing a scan of the internal and external environments of the organization;

- identifying the gaps between what will be needed and what will be available and developing the necessary action plans to bridge the gaps;

- implementing and monitoring these action plans.

\section{Nature of employment equity}

In the South African labour market the disparity in the distribution of jobs, occupations and incomes reveals the effects of discrimination against black people, women and people with disabilities. These designated groups - black people (a generic term encompassing Africans, Coloureds and Indians), women and people with disabilities, are the focus of the Employment Equity Act (Government Gazette, I December 1997: 11).

The approach taken by the Act is that employment equity encompasses both the elimination of unfair discrimination as well as the establishment of specific measures, namely affirmative action measures, to accelerate the advancement of 
persons from the designated groups. The reference to employment equity and to employment equity plans thus reflects the Act's view that the end result is faimess in employment, a concept which is broader than affirmative action measures per se. Cognizance is however taken of the fact that in most instances there will be a need for specific plans and efforts that will involve preferential treatment in appointments and promotions, as well as accelerated development and advancement, and these are commonly referred to as affirmative action measures. Employment equity comprises more than affirmative action however, and there are many other measures that organizations can take which do not necessarily fall under the traditional conceptualization of 'affirmative action', but which have the effect of attaining equity. These measures would be included in the employment equity plans.

Chapter II of the Act specifically prohibits unfair discrimination in that no person may unfairly discriminate, directly or indirectly, against an employee, in any employment policy or practice, on one or more grounds, including race, gender, sex, pregnancy, marital status, family responsibility, ethnic or social origin, colour, sexual orientation, age, disability, religion, HIV status, conscience, belief, political opinion, culture, language and birth. Unfair medical or psychological testing of an employee, as well as workplace harassment (on any one of the above-mentioned grounds), is also regarded as unfair discrimination.

It is not, however, unfair discrimination to take any positive measure consistent with the purposes of the Act, or to distinguish, exclude or prefer any person on the basis of the inherent requirements of a job.

Designated employers include:

- an employer who employs 50 or more employees;

- an employer who employs fewer than 50 employees, but has a total annual tumover that is equal to or above the applicable annual tumover of a small business in terms of Schedule 4 to the Act;

- municipalities;

- an organ of State as defined in section 239 of the Constitution, but excluding local spheres of government, the $\mathrm{Na}$ tional Defence Force, the National Intelligence Agency and the South African Secret Service; - and

- an employer bound by a collective agreement in terms of sections 23 or 31 of the Labour Relations Act, which appoints it as a designated employer to the extent provided for in the agreement.

The duties of designated employers are delineated in Chapter III of the Act, which specifies that every designated employer must, to achieve employment equity, implement affirmative action measures for people from designated groups. A designated employer must:

- consult with its employees;

- conduct an analysis of its employment policies, practices, procedures and working environment;

- conduct a workforce analysis and compile a workforce profile;

- prepare and implement an employment equity plan; and

- report to the Director-General (Labour) on progress made in implementing its employment equity plan.
An employer that is not a designated employer may notify the Director-General that it intends to comply with Chapter III as if it were a designated employer.

The Act applies to all employees and employers except to members of the National Defence Force, the National Intelligence Agency, and the South African Secret Service. The provisions of the Act prohibiting unfair discrimination (Chap ter II) apply to all employees (including applicants for employment) and employers. All employers must take steps to promote equal opportunity in the workplace by eliminating unfair discrimination in any employment policy or practice. The provisions of the Act dealing with affirmative action (Chapter III) only apply to designated employers and people from designated groups.

\section{Purpose and necessity of human risource plan- ning and employment equity}

\section{Purpose and necessity of human resource planning}

The main purpose of human resource planning is to identify future human resource requirements and to develop action plans to eliminate any discrepancies between the demand and supply of labour that may be foreseen (Swanepoel $e t$ al., 1998: 274). According to Dolan \& Schuler (1987: 42), the purposes of human resource planning are more specifically to:

- reduce labour costs by helping management to anticipate shortages or surpluses of human resources, and to correct these imbalances before they become unmanageable and expensive;

- provide a basis for planning employee development that makes optimum use of workers' aptitudes;

- improve the overall business planning process;

- consolidate affirmative action initiatives and so provide more opportunities for specific groups in future;

- promote greater awareness of the importance of sound human resource management throughout all levels of the organization;

- provide an instrument for evaluating the effectiveness of human resource planning actions and policies.

Anderson (1994: 36) motivates human resource planning as valuable to organizations for the following reasons:

- Labour is a significant cost to an organization and planning allows greater control.

- Business planning is a key ingredient of organizational success, and financial, marketing and corporate planning must be augmented by workforce planning.

- Labour supply is not constant and people's social aspirations must be considered, especially in South Africa.

- Environmental changes (technological, political, social and economic) mean that human resource management is becoming more complex and challenging, which makes planning essential.

- Changing product demands have implications for labour (ranging from redundancy to re-training) and planning can help to accommodate these demands.

\section{Purpose and necessity of employment equity}

The purpose of the Employment Equity Act is to achieve equality in the workplace by: 
- promoting equal opportunity and fair treatment in employment through the elimination of unfair discrimination; and

- implementing affirmative action measures to redress the disadvantages in employment experienced by black people, women and people with disabilities, to ensure their equitable representation in all occupational categories and levels in the workforce.

The preamble to the Act states that:

- As a result of apartheid and other discriminatory laws and practices, there are disparities in employment, occupation and income within the national labour market.

- Those disparities create such pronounced disadvantages for certain categories of people that they cannot be redressed simply by repealing discriminatory laws.

The Act is therefore necessary to:

- promote the constitutional right of equality and the exercise of true democracy;

- eliminate unfair discrimination in employment;

- ensure the implementation of employment equity to redress the effects of discrimination;

- achieve a diverse workforce broadly representative of the people of South Africa;

- promote economic development and efficiency in the workforce; and

- give effect to the obligations of the Republic as a member of the International Labour Organization.

\section{Responsibility for human resource planning and employment equity}

\section{Responsibility for human resource planning}

The responsibility for human resource planning is largely contingent upon variables such as the size, nature and complexity of the organization and the extent to which human resource management is performed by specialists or has been devolved to line management. Typically, in very large organizations overall workforce planning will normally be undertaken by a specialist section in the human resource department, with the necessary inputs from line management, whilst in smaller organizations it may be decentralized to the line managers.

Large organizations in South Africa, such as Eskom, Transnet, Anglo American and Telkom, tend to have separate sections staffed by human resource planning specialists at a centralized level utilizing sophisticated human resource information systems to reconcile projections of the demand for labour with forecasts of labour supply.

Swanepoel et al. (1998: 276), however, strongly advocate that, although human resource planning specialists in large organizations may be responsible for driving the overall process, all those affected (for example line managers and employee representatives) should be consulted. In smaller organizations, the same approach holds true, should there be any human resource specialists. With South African organizations facing increasing international competition and pressures to restructure and downsize, it would be particularly advisable to include employee representatives in this process. A thorough human resource plan will not only assist in the smooth execution of any necessary adjustment in the organization but the inclusion of employee representatives in the human resource planning process is specifically required when developing and implementing employment equity programmes.

Likewise, the input of line managers into the human resource planning process is critical; they can provide feedback on aspects such as:

- whether there are enough and appropriate jobs to ensure the output;

- whether there are enough and appropriate job categories;

- whether the incumbents are performing in accordance with accepted standards;

- whether there is a high labour tumover;

- whether more or different product output will necessitate more or different jobs;

- whether a change in product technology will change the job content with a concomitant change in training or recruitment requirements (Swanepoel et al., 1998: 276).

\section{Responsibility for employment equity}

The Employment Equity Act specifies that every designated employer:

- assign one or more senior managers to take responsibility for monitoring and implementing an employment equity plan;

- provide the managers with the authority and means to perform their functions; and

- take reasonable steps to ensure that the managers perform their functions.

This assignment/delegation of responsibility to a manager does not relieve the designated employer of any duty imposed by the Act, which prescribes specifically that the employment equity report that is to be submitted to the Director-General must be signed by the chief executive officer of the designated employer. Top management accountability for employment equity is not avoidable.

All employers must display at the workplace where it can be read by employees a notice, in the prescribed form, informing them about the provisions of the Act. Any alleged contravention, by an employee, of a provision of the Act should immediately be brought to the attention of the employer, who must consult all relevant parties and take the necessary steps to eliminate the alleged conduct, failing which the employer shall be deemed also to have contravened the Act. However, an employer will not be held liable for the conduct of an employee if that employer is able to prove that it did all that was reasonably practicable to ensure that the employee would, not contravene the Act.

Furthermore, designated employers are obliged to take reasonable steps to consult with employees and attempt to reach agreement on the conduct of the two required analyses (that is, the workforce profile and the analysis of employment policies, practices and procedures), the preparation and implementation of employment equity plans, and the reports to be submitted to the Director-General.

\section{A comprehensive model of human resource planning}

Particularly in the current economic climate, organizations are realizing that human resource imbalances with regards to numbers and competencies are proving a serious handicap by 
limiting organizational competitiveness. Human resource planning is not a panacea - in the first place, it is only as good as the information and assumptions upon which it is based, and secondly, it is merely a guide to action; the organization's effectiveness in dealing with its human resource mix will depend not on the sophistication of the plans produced, but on the action actually resulting from the plans.

\section{Phase 1: Human resource demand forecast}

The first step in human resource planning (see Figure 1) is a forecasting exercise which generates information on the organization's future human resource requirements. The purpose is to project what human resources the organization will require in each job category in the future. The time scale of forecasts is idiosyncratic to each organization. Typically, forecast periods range from one year to five years. (Yet, despite the benefits of longer-term human resource planning, most current forecasting of labour supply and demand is short range and used for the purpose of budgeting and cost control [Swanepoel et al., 1998: 285]).

Hofmeyr (1980: 7) advocates that before the factors influencing this forecast are considered, they are preceded by an investigation phase to try to eradicate as far as possible any existing misutilization of human resources. Questions to be addressed include: Are the correct numbers of employees being currently employed in the various categories? Does the work need to be done? Are employees equipped with the necessary skills and resources?

\section{Strategic plans}

In order to estimate what human resources will be required in the future, the human resource planner must be acquainted with the organization's short- and longer-term goals. These include strategic objectives for various services and product lines, including plans for expansion, contraction and diversification. Decisions to expand market share, enter new (for example, international) markets, or relocate would also need to be considered. In addition, more detailed divisional targets, such as production schedules and budgets, are necessary and the human resource planner must have access to such information.

\section{Economic trends}

Fluctuations from prosperity to recession and back to prosperity pose considerable frustrations for the human resource planner. Though economic predictions are notoriously difficult to make with accuracy, some consideration must be given to the level of economic activity when planning human resource requirements. Economic trends influence the growth in projected job vacancies for various occupations, while forcing outright declines in others. Forecasting in stable organizations tends to be more accurate than in organizations immersed in volatile environments.

\section{Technological trends}

Advances in technology influence the nature and mix of jobs required. For example, computer technology decreases the need for bookkeepers and increases the need for computer programmers. Improvements in information and communication technology (for example, fax machines, the personal computer, e-mail, and the internet) are revolutionizing job tasks and environments.

\section{Organizational structure}

Two major determinants of organizational structuring are currently exerting considerable influence on South African (and in fact many international) organizations, namely information technology and competitiveness. Organizations are being restructured as a result of mergers, downsizing, and the decreased need for certain levels of (mainly middle) management. The waning and changing demand for particular jobs, especially managerial, and the resultant desired organizational structure, exerts a significant influence on human resource demand forecasts.

\section{Employment equity}

Not only are the projected numbers per job category per year necessary for the human resource demand forecast, but information on the desired make-up of these numbers, for example, what mix of male versus female, formally qualified versus informally qualified, black versus white, is also necessary. With the advent of employment equity legislation, human resource planning has to take into account the organization's overall staff mix, specifically with regards to the number of people from designated groups and their representation in all occupational categories and levels in the workforce of a designated employer. Cognizance of the regional and national demographics relating to the economically active population should be taken at this point.

The human resource planner will estimate, for each job category, how many people, and of what type, are required in the short and longer term. There are various methods of forecasting: from rudimentary forecasting using largely managerial judgement, to sophisticated techniques utilizing statistical methods. Statistical methods are used mainly to capture historical trends in an organization's demand for human resources and can, given the right conditions, provide much more accurate predictions than judgemental processes. In other circumstances the judgemental approach is more appropriate, for example in the absence of historical data regarding events occurring in the marketplace or in an organization. To achieve an appropriate and balanced result, workforce planners should ideally combine statistical and judgemental approaches when forecasting (Swanepoel et al., 1998: 277). Although many sophisticated forecasting techniques have been developed, forecasting often remains informal and judgemental.

Appendix A provides a summary of various methods that can be used to forecast human resource demand and supply. These methods are divided into two major groups: those that rely on statistical formulas (quantitative) and those that rely on expert judgements (qualitative).

\section{Phase 2: Human resource supply forecast}

The human resource planner now has to assess the human resources currently available in the organization, and make a forecast of what will be available for the forecast period. This includes an internal assessment of existing staff and a consideration of the factors which will influence their make-up 


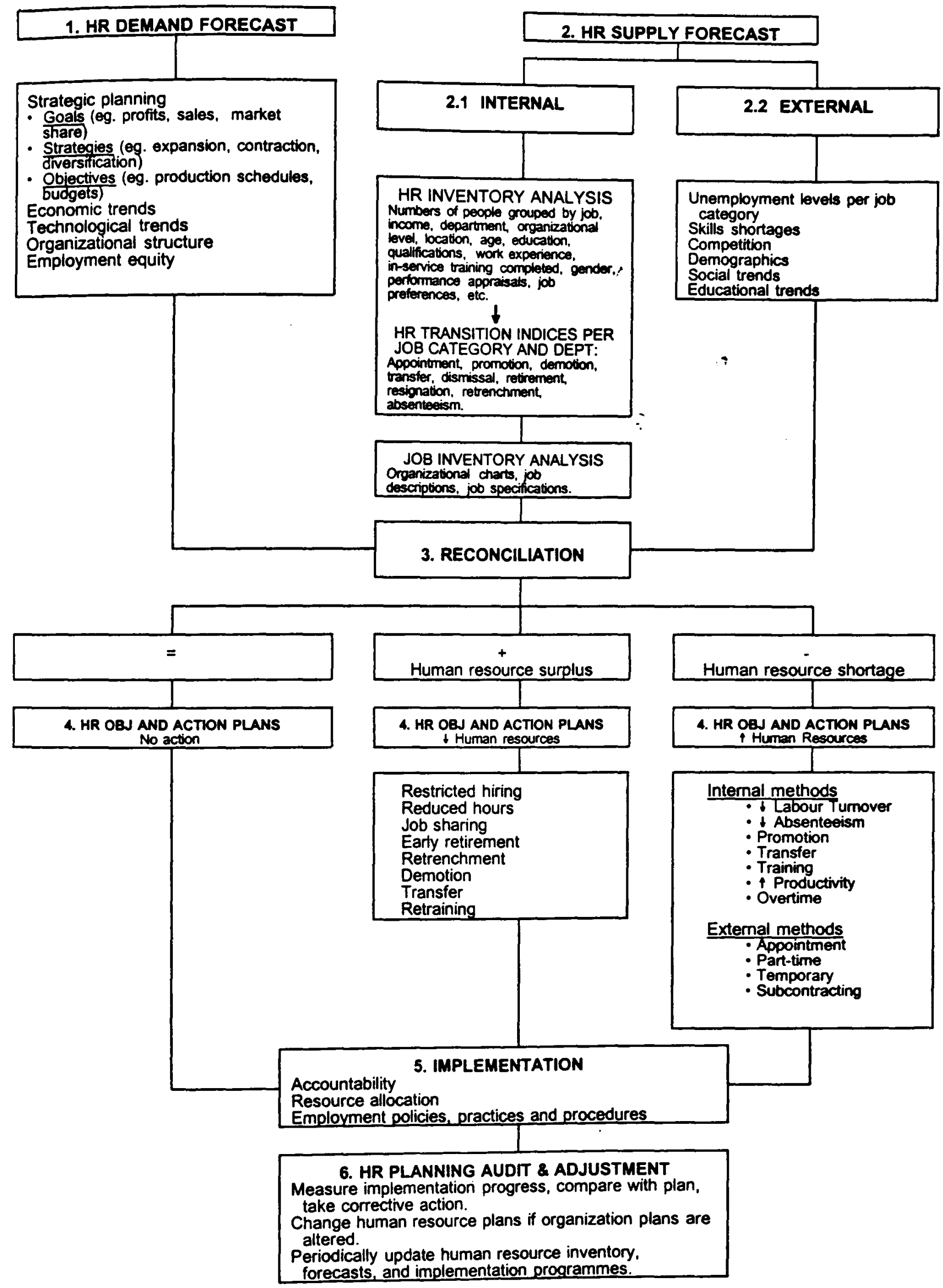

Figure 1 A comprehensive human resource planning model

during the forecast period, as well as a forecast of the availability of human resources extemal to the organization from which needed people can be drawn.
Phase 2.1 Internal human resource supply forecasi

This phase entails an analysis of the inventory of the current workforce and the current jobs in the organization. 
Human resource inventory analysis. Questions that need to be asked at this stage include: Who are our employees? What skills do they have? How well do they perform? How well are they developed? Details of the skills, competencies, interests, and preferences of the current workforce are important items in the human resource data bank.

Human resource transition indices. An analysis of the trends and factors which affect the size, composition and effectiveness of the workforce form an integral part of predicting fluctuations in the existing workforce profile. An examination, per job category and department, of trends reflecting the movement of employees into, within, and out of the organization should be undertaken. Labour turnover trends are indicators of the numbers of staff who will be lost to each job category in the future. Hofmeyr (1980:7) advises that the human resource planner look behind this labour turnover data at this point and investigate how long employees characteristically stay with the organization, by job category. This can be a useful exercise, especially if it includes an examination of other ratios, for example skilled versus unskilled, black versus white, female versus male, as it identifies problem areas which can remain hidden by overall labour turnover statistics. Promotion and transfer patterns also have to be taken into account as these patterns will affect 'losses' from job categories in the future. Other ratios within these patterns should similarly be considered. Statistics on appointments, promotions, demotions, transfers, dismissals, resignations, retrenchments, age (reflecting employees approaching mandatory retirement), and absenteeism (which reduces the number of personnel actually available for work) will prove valuable in improving the accuracy of forecasts.

Job inventory analysis. Not only should the human resource planner have a clear picture of the present workforce, it is also important to determine the characteristics of present jobs in the organization, how they are organized and structured, and the skills required to fill them (Swanepoel $e t$ al., 1998: 279). Organizational charts would prove useful in this regard, and proper job analysis would facilitate this part of the inventory. The value of an updated (computerized) record of all the jobs in an organization and competency requirements of all levels, cannot be overemphasized. Many organizations fail to produce credible workforce plans because of the lack of accurate information on job requirements - in other words, job descriptions and specifications (Ibidem).

Similarly, equity legislation prescribes the conduct of a workforce analysis, though smaller in extent and more focused in nature than the human resource inyentory analysis. Each designated employer must prepare a profile of its workforce illustrating within each occupational category and level the degree of underrepresentation of people from designated groups. Furthermore, the employer must collect information and conduct an analysis of its employment policies, practices, procedures and the working environment, to identify employment barriers which adversely affect people from designated groups. Both analyses are to be conducted in consultation with employees.

Swanepoel et al. (1998: 164) propose a list of criteria that could be included in such analyses. Specifically, an employment equity audit should provide information on:
- Employment, pay and benefits in major categories by race, gender and disability;

- Programmes and policies on human resource development, including levels of expenditure, certification, and the race, gender and disability status of trainees;

- Organization of work in terms of the skills and responsibilities required by different positions and hours worked;

- Transport, housing and caring arrangements and preferences of employees, by race and gender, including options for hours worked;

- Languages used and language competence;

- Physical facilities for disabled people and women;

- Procedures for hiring, training, promotion, retrenchment and transfers; and

- Grievance and internal appeals procedures.

The data produced by the employment equity audit and the analysis of employment barriers will provide the basis of the employment equity plan.

\section{Phase 2.2 External human resource supply forecast}

The next step is an investigation of the likely supply of human resources available from outside the organization. If the human resource plan evinces future labour shortages, will it be possible to recruit the necessary number and type of people with the appropriate skills from the labour market? Information should be gathered on factors such as:

- unemployment levels per job category (indicative of labour availability);

- skills shortages (a warning of possible difficulties in obtaining the required type of employee);

- competition (indicative of proximate contenders for sought-after labour; but also a possible source of poaching);

- demographics (factors to consider include age, gender, race, ethnicity, disability, language and culture - these will become increasingly important as employment equity initiatives are effectuated; the current and predicted impact of AIDS might also be a relevant influence on labour availability);

- social trends (for example, reduced or increased labour flexibility as per employee attitudes regarding relocation); and

- educational trends (for example, university and technikon data).

\section{Phase 3: Reconciliation}

In summary, phase 1 first estimates the future demand for human resources, per job category, for the forecast period having considered the organization's plans for the future and various other influences, including governmental regulations like employment equity. Phase 2 then investigates the internal supply of labour, presently and in the future, together with an examination of how this workforce is made up in terms of skill levels, age, race, gender, and the like. Data regarding the availability of human resources in the external labour market is also gathered.

In phase 3, the human resource planner compares the forecast demand for human resources with the likely supply from internal sources and the likely availability from external sources. This step focuses on the process of reconciliation 
necessitated by the mismatch usually produced between the quantitative and qualitative demand for employees based on the future plans of the organization and on current projections of employee availability for the forecast period. Shortfalls in human resources may result in departments running at overcapacity due to employee shortages, possibly necessitating overtime work - with associated long-term problems. Surplus of employees may, on the other hand, lead to low productivity, financial losses and, if employees are not transferred, retrained or retrenched, to the eventual closing of the organization. The human resource planner, together with key line and staff personnel, must now design strategies to ensure that the necessary human resources are available when needed.

The senior manager(s) responsible for employment equity will likewise have to consult with employees on evinced discrepancies between the current human resource profile of the organization and an equitable employment state for specifically blacks, women and people with disabilities, with a view to devising an employment equity plan to address any disparities.

\section{Phase 4: Human resource objectives and action plans}

Specific human resource objectives and accompanying action plans are required to give effect to the reconciliation process by reducing the manifest discrepancies, if any, between projections of the demand and supply of labour for the forecast period.

Human resource objectives are directly related to general organizational objectives and strategies. However, according to a survey in the United States of America, only about $25 \%$ of organizations achieve a substantial link between their general institutional planning and their human resource planning (Dolan \& Schuler, 1987: 53).

This phase focuses on the desired end result and on providing targets to measure the achievement of success in addressing the labour surpluses or shortages in the organization. Definite objectives (including a timetable for their achievement) should be set to measure effectiveness (for example, that the number of packers at a particular depot be increased by $15 \%$ within the next year). Once human resource objectives have been set, action plans must be formulated to facilitate their achievement. Responsibilities must also be assigned to different persons for the execution of the action plans.

\section{Remedying human resource surpluses}

A number of strategies exist to reduce an anticipated labour surplus in an organization, for example retrenchment, demotions and transfers. Such decisions can be speedily executed, but the possibly harsh impact on employees (both those directly affected and the survivors) and the grim consequences for the organization can be severe.

Other options which are slower to take effect but which tend to be considerably less traumatic to implement are freezing positions or restricted hiring following resignations or normal retirement, providing incentives to encourage early retirement, implementing reduced working hours (in return for sustained employment), job sharing (where two or more people share the responsibilities and benefits of a single fulltime job), and the retraining of staff to acquire needed competencies
Remedying human resource shortages: internal methods

The human resource demand forecast should ideally have been preceded by an attempt to eradicate obvious productivity wastages. At this stage of action planning. however, it may be expedient to bridge the gap between the demand and supply of labour by means of a planned productivity improvement. This type of programme would enhance the effectiveness of the workforce and increase the supply of human resources available without increasing the number of personnel (Flippo, 1984: 137). Strategies to reduce absenteeism would have the same effect. High labour turnover, in most cases, is undesirable and costly to the organization. Reducing labour turnover, apart from generating a direct cost saving to the organization, also reduces the gap between the demand and supply of labour, and is particularly valuable when a significant shortage is predicted in a category where the external labour supply appears unlikely to be able to provide the numbers required. It may be possible to speed up promotion into a particular category in order to forestall a forecast shortage - this would obviously have to be executed in close conjunction with the action plans for training and development. Transferring workers from one job category or division to another provides another alternative for balancing staff levels. Overtime provides a quick remedy to labour shortfalls, whereas training and development remains one of the choice altematives to meeting human resource needs, and particularly from an employment equity perspective provides multiple benefits to all parties.

\section{Remedying human resource shortages: external methods}

Employing part-time, temporary, or subcontracted workers can prove expeditious altematives to coping with labour insufficiencies (bearing in mind that the Labour Relations Act of 1995 prohibits the use of temporary employees under certain conditions). The information on existing staff ratios (black to white, et cetera) in comparison with the desired ratios for the future allow for a recruitment strategy aimed at appointing human resources who will change these ratios.

Similarly, designated employers must prepare and implement an employment equity plan which will achieve reasonable progress towards employment equity in that employer's workforce. Designated employers employing fewer than 150 employees have 12 months after commencement of the Act (or after the date on which they became a designated employer) to submit their first report. Employers of 150 or more employees have six months to submit their initial report.

The employment equity plan must state:

- the objectives to be achieved for each year of the plan;

- the affirmative action measures to be implemented, which are measures designed to ensure that people from designated groups have equal employment opportunities and are equitably represented in all occupational categories and levels in the workforce of a designated employer, and must include:

- measures to identify and eliminate employment barriers, including unfair discrimination, identified in the analysis, which adversely affect people from designated groups; 
- measures designed to further diversity in the workplace based on the equal dignity and respect of all people; - making reasonable accommodation of people from designated groups to ensure that they enjoy equal opportunities and are equitably represented in the workforce;

- measures, including preferential treatment and numerical goals, to ensure the equitable representation of suitably qualified people from designated groups in all occupational categories and levels in the workforce; and

- measures to retain, train and develop people from designated groups;

- where underrepresentation of people from designated groups has been identified by the analysis, the numerical goals to achieve the equitable representation of suitably qualified people from designated groups within each occupational category and level in the workforce, the timetable within which this is to be achieved, and the strategies intended to achieve those goals;

- the timetable for each year of the plan for the achievement of goals and objectives other than numerical goals;

- the duration of the plan, which may not be shorter than one year or longer than five years;

- the procedures that will be used to monitor and evaluate the implementation of the plan and whether reasonable progress is being made towards implementing employment equity;

- the internal procedures to resolve any dispute about the interpretation or implementation of the plan;

- the persons in the workforce, including senior managers, responsible for monitoring and implementing the plan; and

- any other matter that may be prescribed, or which is consistent with the purposes of the Act.

Every designated employer, when submitting initial and subsequent employment equity reports, must submit a statement to the Employment Conditions Commission on the remuneration and benefits received in each occupational category and level of the workforce, and where disproportionate income differentials are reflected in this statement, take measures to reduce such differentials.

\section{Phase 5: Implementation}

Once human resource goals have been set, individuals must be held accountable for the planned actions and the necessary resources must be made available. Plans relating to recruitment, training and development, increased labour productivity, retirements and retrenchments must be buttressed by valid and fair employment policies, practices and procedures.

Accountability for employment equity rests upon the chief executive officer of the designated employer. As mentioned previously, a designated employer may assign and equip one or more senior managers to take responsibility for monitoring and implementing the employment equity plans but retains ultimate accountability and liability.

Employment equity legislation compels a detailed analysis of the employment policies, practices, procedures and working environments of each designated employer, with the stated intention of identifying and consequently eliminating any employment barrier which adversely affects blacks, women or people with disabilities.
The extent to which a designated employer is complying with the Act in implementing employment equity will be specifically assessed by the Director-General on a regular basis. Guidelines for this assessment are provided in the following section.

\section{Phase 6: Human resource planning audit and adjust- ment}

For various reasons, the programmes for meeting human resource targets may fall short of objectives. A mechanism for assessing progress should be installed. Multiple measures can be used, depending on the specific programme being evaluated. For example, what percentage of the organization's electricians have acquired their wireman's licence (if the goal is to upgrade the electrical department personnel)? How many apprentices are graduating each year from the machinist apprenticeship programme (if the goal is to 'grow from within' skilled tradespersons)? What percentages of first-, second-, third-, and fourth-level managerial positions are now occupied by women and blacks (if affirmative action goal accomplishment is being monitored)? If results fall short of targets, corrective action should be taken.

Possible criteria or standards for evaluating human resource planning include the measurement of (Dolan \& Schuler, 1987: 59):

- actual staffing levels against established staffing requirements;

- productivity levels against established goals;

- actual personnel flow rates against desired rates;

- programmes implemented against action plans;

- programme results against expected outcomes (for example improved applicant flows, reduced resignation rates, improved replacement ratios);

- labour and programme costs against budgets; and

- ratios of programme results (benefits) to programme costs.

Progress on goal achievement is also necessary to ascertain whether changes in the human resource objectives and plans are necessitated by altered conditions or because specific original forecast assumptions have been proven wrong (Beach, 1985: 122).

Progress on goal achievement with regards to employment equity will be assessed by the Director-General. In determining whether a designated employer is implementing employment equity in compliance with the Act, the following factors will be taken into account:

- the extent to which affirmative action measures have been implemented;

- the extent to which people from designated groups are equitably represented within each occupational category and level in that employer's workforce in relation to the:

- demographic profile of the national and regional economically active population;

- pool of suitably qualified people from designated groups from which the employer may reasonably be expected to appoint or promote employees;

- economic and financial factors relevant to the sector in which the employer operates;

- present and anticipated economic and financial circumstances of the employer; and 
- the number of present and planned vacancies that exist in the various job categories and levels, and the employer's labour turnover;

- progress made in implementing employment equity by other designated employers operating under comparable circumstances and within the same sector;

- reasonable efforts made by a designated employer to implement its employment equity plan;

- the extent to which the designated employer has made progress in eliminating employment barriers that adversely affect people from designated groups; and

- any other prescribed factor.

Before the end of the term of its current employment equity plan, a designated employer must prepare a subsequent employment equity plan. Employers who employ fewer than 150 employees will be required to submit their subsequent reports once every two years, whereas employers employing 150 or more employees will submit their subsequent reports every year.

Periodic updates of the human resource inventory will facilitate updates of the human resource supply forecast, which can in tum be fed through to adjust the human resource plans and implementation programmes, and concomitantly expedite the formulation and submission of subsequent employment equity reports.

\section{Conclusion}

The employment equity plan necessitated by the Employment Equity Act (1998) is required to be an extremely thorough document, the preparation and development of which is based on a meticulous analysis of both the existing workforce and the prevailing employment policies, practices, procedures and working environment, to detect and remedy inequities in workforce composition and employment barriers that adversely affect blacks, women and people with disabilities.

Organizations that deliberately engage in human resource planning are seeking to maximize the cost-saving probability of having the right number and the right kind of human resources in the right place at the right time in order to effectively and efficiently deliver a particular level of output or service in the future. In a time of economic, social, political and organizational change such as South Africa is currently engulfed in, human resource planning is not a luxury but an organizational imperative.

Fortuitously, the activities associated with employment equity are mirrored and augmented in the human resource planning process:

- Both processes require consultation with affected parties.
- The preparation of an employment equity workforce analysis, reflecting the position of blacks, women and people with disabilities in the organization, should not be seen in isolation from the human resource inventory analysis required for forecasting the internal supply of labour

- The analysis of existing employment policies, practices and procedures to determine their support or hinderance of employment equity reflects the same need for fair, lawful and effective human resource policies and practices to buttress the implementation of human resource plans.

- Preparing and implementing employment equity plans to redress workforce inequities should be incorporated in broader human resource action plans to address projected shortfalls or surpluses of human resources.

- The periodic submission af updated employment equity reports demonstrating progressive reduction of employment inequities can suitably be incorporated into the human resource ptanning audit and adjustment.

Organizations choosing to give effect to employment equity dictates within the broader process of human resource planning will experience the serendipitous benefit of comprehensively satisfying organizational and legislative requirements simultaneously.

\section{References}

Anderson, A.H. 1994. Effective personnel management: dskills and activity-based approach. Oxford: Blackwell.

Beach, D.S. 1985. Personnel: the management of people at work. New York: Macmillan.

Dolan, S.L. \& Schuler, R.S. 1987. Personnel and human resource management in Canada. New York: West Publishing Company

Flippo, E.B. 1984. Personnel management. New York: McGrawHill.

French, W. 1994. Human resource management. 3rd ed. Boston: Houghton Mifflin.

Gomez-Mejia, L.R., Balkin, D.B. \& Cardy, R. 1995. Managing human resources. Englewood Cliffs NJ: Prentice-Hall.

Employment Equity Act. 1 December 1997. Government Gazette. Republic of South Africa, Vol. 390, No. 18481, Pretoria.

Employment Equity Act. 19 October 1998. Government Gazette, Republic of South Africa, Vol. 400, No.19370, Cape Town.

Hercus, T. 1993. Workforce planning in eight British organizations: a Canadian perspective. In Handbook of workforce management, Towers, B. ed. Oxford: Blackwell.

Hofmeyr, K. 1980. Manpower planning: how to do it, People and Profits, June: 5-8

Swanepoel, B.J., Erasmus, B.J., Van Wyk. M.W. \& Schenk. H.W. 1998. South African human resource management: theory and practice. Kenwyn: Juta.

Appendix A Quantitative and qualitaitive methods of forecasting human resource demand and supply

\begin{tabular}{|c|c|c|c|}
\hline \multicolumn{4}{|c|}{ Quantitative methods of forecasting humen resource demend } \\
\hline Mothod & Description & Advanteges & Disedventages \\
\hline Moving average & $\begin{array}{l}\text { - Averages data about HR } \\
\text { demand from recent } \\
\text { periods and projects them } \\
\text { into the future. }\end{array}$ & - Simplicity. & $\begin{array}{l}\text { - Seasonal or cyclical } \\
\text { patterns may be ignored. } \\
\text { - Relies on past data. }\end{array}$ \\
\hline
\end{tabular}




\begin{tabular}{|c|c|c|c|}
\hline Exponential smoothing & $\begin{array}{l}\text { - Forecasters can vary } \\
\text { weights for HR demand } \\
\text { assigned to different past } \\
\text { time periods used to } \\
\text { project future HR } \\
\text { demand. }\end{array}$ & $\begin{array}{l}\text { - May be used to take } \\
\text { into account factors } \\
\text { ignored by the moving } \\
\text { average method (e.g.. } \\
\text { cyclical patterns). }\end{array}$ & $\begin{array}{l}\text { Mathematical complexity. } \\
\text { - Choice of weights may be } \\
\text { arbitrary. } \\
\text { Relies on past data. }\end{array}$ \\
\hline Trends projections & $\begin{array}{l}\text { Numbers of people hired } \\
\text { or requested placed on } \\
\text { one axis; time is placed } \\
\text { on the other axis. A } \\
\text { straight line is plotted } \\
\text { from past to future to } \\
\text { predict HR demand. }\end{array}$ & $\begin{array}{l}\text { - Easily explained to } \\
\text { managers. } \\
\text { - Easily prepared by HR } \\
\text { planners. }\end{array}$ & $\begin{array}{l}\text { Rough estimates. } \\
\text { - Relies on past data. }\end{array}$ \\
\hline Regression & $\begin{array}{l}\text { - Mathematical formula } \\
\text { used to relate staffing to } \\
\text { several variables le.g., } \\
\text { output, product mix, per } \\
\text { capita productivityl. }\end{array}$ & $\begin{array}{l}\text { - Can include many } \\
\text { variables. } \\
\text { Efficient use of all } \\
\text { available data. }\end{array}$ & $\begin{array}{l}\text { - Mathematical complexity. } \\
\text { - Requires large sample sizes. } \\
\text { - Relies on past data. }\end{array}$ \\
\hline Linear programming & $\begin{array}{l}\text { Assesses required } \\
\text { staffing level that } \\
\text { matches desired output } \\
\text { levels, subject to certain } \\
\text { constraints (e.g.., budget, } \\
\text { cost). }\end{array}$ & $\begin{array}{l}\text { - Assesses what should } \\
\text { be in the future, not } \\
\text { what probably will be. }\end{array}$ & $\begin{array}{l}\text { - Managers are sceptical of } \\
\text { highly sophisticated } \\
\text { methodology. } \\
\text { Numerous assumptions } \\
\text { must be made. }\end{array}$ \\
\hline Actuarial models & $\begin{array}{l}\text { - Relate turnover to such } \\
\text { factors as age and } \\
\text { seniority. }\end{array}$ & - Reflect past. & $\begin{array}{l}\text { - May not be accurate in } \\
\text { individual cases. }\end{array}$ \\
\hline Simulations & $\begin{array}{l}\text { - Use scenarios to test the } \\
\text { effect of various } \\
\text { personnel policies. }\end{array}$ & $\begin{array}{l}\text { Useful for considering } \\
\text { alternative HR } \\
\text { programmes. } \\
\end{array}$ & - Accuracy varies. \\
\hline Probability matrixes & $\begin{array}{l}\text { - Define "states" in the } \\
\text { organisation - such as } \\
\text { strategy levels, } \\
\text { performance ratings. } \\
\text { - Identify time period. }\end{array}$ & $\begin{array}{l}\text { - Help identify career } \\
\text { patterns. } \\
\text { - Help perform turnover } \\
\text { analysis. }\end{array}$ & $\begin{array}{l}\text { - Require some mathematical } \\
\text { sophistication. } \\
\text { - Accuracy varies. }\end{array}$ \\
\hline $\begin{array}{l}\text { First-order Markov } \\
\text { model }\end{array}$ & $\begin{array}{l}\text { Multiply number of } \\
\text { people in each job } \\
\text { category by the } \\
\text { probability of movement } \\
\text { between job/position } \\
\text { categories. Model } \\
\text { assumes that current } \\
\text { job/position category is } \\
\text { the chief determinant of } \\
\text { movement. }\end{array}$ & $\begin{array}{l}\text { - Adequate for } \\
\text { considering alternative } \\
\text { effects of various HR } \\
\text { strategies. }\end{array}$ & $\begin{array}{l}\text { - Not adequate for long-term } \\
\text { forecasts. } \\
\text { Requires mathematical } \\
\text { sophistication. }\end{array}$ \\
\hline Semi-Markov model & $\begin{array}{l}\text { Same as first-order } \\
\text { Markov model except } \\
\text { that probability of } \\
\text { movement is determined } \\
\text { by: (1) job/position } \\
\text { category, and }(2) \text { the } \\
\text { individual's length of stay } \\
\text { in the job class. }\end{array}$ & $\begin{array}{l}\text { - More inclusive than a } \\
\text { first-order Markov } \\
\text { model. }\end{array}$ & $\begin{array}{l}\text { - Not very useful for } \\
\text { considering alternative } \\
\text { effects of various HR } \\
\text { strategies. } \\
\text { - Requires mathematical } \\
\text { sophistication. }\end{array}$ \\
\hline \multicolumn{4}{|c|}{ Qualitative methods of forecasting human resource demand and supphy } \\
\hline Dephi technique & $\begin{array}{l}\text { A group of experts } \\
\text { exchanges several rounds } \\
\text { of estimates of HR } \\
\text { demand or supply. } \\
\text { normally without meeting } \\
\text { face to face. Feedback } \\
\text { from other experts is } \\
\text { used by each individual } \\
\text { to "fine-tune" his/her } \\
\text { independent estimate. }\end{array}$ & $\begin{array}{l}\text { - Can involve key } \\
\text { decision makers in } \\
\text { process. } \\
\text { Can focus on what is } \\
\text { expected or desired in } \\
\text { future. } \\
\text { Not bound to the past. }\end{array}$ & $\begin{array}{l}\text { - Highly subjective. } \\
\text { Judgments may not } \\
\text { efficiently use objective } \\
\text { data. }\end{array}$ \\
\hline $\begin{array}{l}\text { Nominal Group } \\
\text { Technique }\end{array}$ & $\begin{array}{l}\text { A small group of experts } \\
\text { meet face to face. } \\
\text { Following a procedure } \\
\text { that involves open } \\
\text { discussion and private } \\
\text { assessments, the group } \\
\text { reaches a judgement } \\
\text { concerning future HR } \\
\text { demand or supply. } \\
\end{array}$ & $\begin{array}{l}\text { - Same as for Delphi } \\
\text { technique } \\
\text { Group discussions can } \\
\text { facilitate exchange of } \\
\text { ideas and greater } \\
\text { acceptance of results } \\
\text { by participants. }\end{array}$ & $\begin{array}{l}\text { - Same as for Delphi } \\
\text { technique. } \\
\text { - Group pressure may lead to } \\
\text { less accurate assessments } \\
\text { than could be obtained } \\
\text { through other means. }\end{array}$ \\
\hline
\end{tabular}

SOURCE: William J. Rothwell and H.C. Kazanas, Strategic Humon Resources Plonning and Manogement (Englewood Cliffs NJ: Prentice Hall, 1988) as it appears in Luis R. Gomez-Mejia, David B. Balkin and Robert Cardy, Managing Human Resources (Englowood Cliffs NJ: Prentice Hall, 1995): pp.76-77. 